\title{
Pengaruh Model Pembelajaran Kooperatif Tipe Course Review Horay Bermediakan Audio Visual Terhadap Hasil Belajar IPA
}

\author{
Tjokorda Istri Mirah Satya Dewi $\mathrm{P}^{1 *}$, I Gede Margunayasa ${ }^{2}$, Nyoman Kusmariyatni ${ }^{3}$
}

123Jurusan Pendidikan Guru Sekolah Dasar, Universitas Pendidikan Ganesha, Indonesia

\author{
A R T I C LEINFO \\ Article history: \\ Received 18 February \\ 2019 \\ Received in revised form \\ 20 March 2019 \\ Accepted 20 April 2019 \\ Available online 20 May \\ 2019 \\ Kata Kunci: \\ audio visual, $\mathrm{CRH}$, hasil \\ belajar \\ Keywords: \\ audiovisual, $\mathrm{CRH}$, learning \\ achievement.
}

\begin{abstract}
A B S T R A K
Penelitian ini bertujuan untuk mengetahui perbedaan yang signifikan hasil belajar IPA antara kelompok siswa yang mengikuti model pembelajaran kooperatif tipe Course Review Horay bermediakan audio visual dan kelompok siswa yang mengikuti pembelajaran konvensional pada siswa kelas V SD di Gugus III Kecamatan Sukawati Tahun Pelajaran 2017/2018. Penelitian ini termasuk pada penelitian jenis eksperimen semu dengan menggunakan rancangan nonequivalent post-test only control group design. Populasi penelitian adalah seluruh siswa kelas V SD di Gugus III Kecamatan Sukawati dengan jumlah siswa 150. Teknik pengambilan sampel yang digunakan adalah random sampling. Sampel penelitian ini adalah kelas $\mathrm{V}$ di SD Negeri 2 Batuan Kaler dan SD Negeri 4 Batuan. Pengumpulan data dilakukan dengan metode tes dan menggunakan instrumen tes pilihan ganda yang berjumlah 30 butir soal. Data yang diperoleh dianalisis dengan menggunakan teknik analisis deskriptif dan statistik inferensial (uji-t) dengan rumus polled varians. Berdasarkan hasil analisis data hasil belajar IPA, terdapat perbedaan yang signifikan hasil belajar IPA antara kelompok siswa yang mengikuti model pembelajaran kooperatif
\end{abstract} tipe Course Review Horay bermediakan audio visual dan kelompok siswa yang mengikuti pembelajaran konvensional. Rata-rata hasil belajar IPA kelompok eksperimen $(23,58)$ lebih tinggi daripada kelompok kontrol $(15,23)$. Hasil penelitian menunjukkan bahwa model pembelajaran kooperatif tipe Course Review Horay bermediakan audio visual berpengaruh terhadap hasil belajar IPA siswa kelas V SD di Gugus III Kecamatan Sukawati Tahun Pelajaran 2017/2018.

\section{A B S T R A C T}

This research aimed to determine the significant difference of natural science learning achievement between group of students who learned natural science with cooperative learning model type $\mathrm{CRH}$ supported by audio-visual as the learning media and group of students who learned it with conventional learning in fifth-grade elementary school students of Cluster III Sukawati subdistrict in the academic year of 2017/2018. This research was a quasi-experimental research with non-equivalent post-test only control group design. This research population was all of the grade $\mathrm{V}$ of elementary school students which consisted of 150 students. Random sampling was the sampling technique for this research. Samples of this research were the fifth-grade students in SD Negeri 2 Batuan Kaler dan SD Negeri 4 Batuan. The data were collected using a test method and using a multiple choice test instrument consisting of 30 items. The collected data were analyzed by descriptive analysis and inferential statistic technique using a pooled variance type of $t$-test. Based on the analysis result, there was a significant difference in students natural learning achievement between the group of cooperative learning model type Course Review Horay supported by audiovisual media and group of students who learned natural science with conventional learning. The natural science learning achievement average for the experiment group is $(23,58)$ higher than the control group $(15,23)$. The result of this research shows that cooperative learning model type Course Review Horay supported by audiovisual media have an effect on the fifth-grade students' natural science learning achievement in Cluster III Sukawati subdistrict in the academic year of 2017/2018.

Copyright (C) Universitas Pendidikan Ganesha. All rights reserved.

\footnotetext{
${ }^{1}$ Corresponding author.

E-mail addresses: mirahcok@gmail.com (Tjokorda Istri Mirah Satya Dewi P)
} 


\section{Pendahuluan}

Pendidikan merupakan hal yang sangat penting bagi manusia. Melalui pendidikan manusia dapat meningkatkan kemampuan serta mengembangkan potensi, pengetahuan, keterampilan dan kreativitas yang dimiliki secara optimal. Saat ini Lembaga pendidikan dituntut untuk dapat menyelenggarakan proses pendidikan secara optimal sebagai upaya untuk meningkatkan kualitas dan mutu pendidikan. Pendidikan yang baik adalah pendidikan yang tidak hanya mempersiapkan para siswanya untuk sesuatu profesi atau jabatan, tetapi untuk menyelesaikan masalah-masalah yang dihadapinya dalam kehidupan sehari-hari (Trianto, 2009:5).

Pendidikan juga merupakan suatu proses yang diperlukan untuk mendapatkan keseimbangan dan kesempurnaan dalam perkembangan individu maupun masyarakat. Penekanan pendidikan dibanding dengan pengajaran terletak pada pembentukan kesadaran dan kepribadian individu atau masyarakat di samping transfer ilmu dan keahlian. Dengan proses semacam ini suatu bangsa atau negara dapat mewariskan nilai-nilai keagamaan, kebudayaan, pemikiran dan keahlian kepada generasi berikutnya, sehingga mereka betul-betul siap menyongsong masa depan kehidupan bangsa dan negara yang lebih cerah (Nurkholis, 2013).

Pasal 1 UU SISDIKNAS no. 20 tahun 2003 disebutkan bahwa Sistem Pendidikan Nasional adalah keseluruhan komponen pendidikan yang saling terkait secara terpadu untuk mencapai tujuan pendidikan nasional. Berangkat dari bunyi pasal ini dapat diketahui bahwa pendidikan adalah sistem yang merupakan suatu totalitas struktur yang terdiri dari komponen yang saling terkait dan secara bersama menuju kepada tercapainya tujuan (Soetarno, 2003: 2). Adapun komponen-komponen dalam pendidikan nasional antara lain adalah lingkungan, sarana-prasarana, sumberdaya, dan masyarakat. Komponen-komponen tersebut bekerja secara bersama-sama, saling terkait dan mendukung dalam mencapai tujuan pendidikan (Munirah, 2015).

Ini sejalan dengan tujuan pendidikan nasional yang tertuang dalam Undang-Undang Republik Indonesia No. 20 tahun 2003, Bab II pasal 3 yaitu, bertujuan untuk berkembangnya potensi peserta didik agar menjadi manusia yang beriman dan bertakwa kepada Tuhan Yang Maha Esa, berakhlak mulia, sehat, berilmu, cakap, kreatif, mandiri dan menjadi warga negara yang demokratis dan bertanggung jawab. Agar mencapai tujuan pendidikan tersebut maka pemerintah melakukan berbagai cara seperti meningkatkan mutu pendidikan.

Sekolah sebagai suatu lembaga pendidikan formal tentunya menyediakan berbagai kesempatan bagi peserta didik untuk melakukan kegiatan belajar. Melalui berbagai kesempatan belajar di sekolah, pertumbuhan dan perkembangan peserta didik di arahkan dan di dorong ke pencapaian tujuan yang dicita-citakan. Melaksanakan proses pembelajaran, seorang guru perlu memiliki kemampuan dalam merancang proses pembelajaran. Untuk itu seorang guru harus mampu melaksanakan proses pembelajaran yang efektif dan menyenangkan pada semua mata pelajaran di sekolah. Proses pembelajaran yang demikian harus dilaksanakan pada semua mata pelajaran di sekolah dasar. Salah satu mata pelajaran yang diajarkan di sekolah dasar yaitu Ilmu Pengetahuan Alam (IPA), karena IPA merupakan salah satu cabang ilmu pengetahuan yang memegang peranan penting dalam perkembangan IPTEK. Ilmu Pengetahuan Alam merupakan terjemahan dari kata-kata Bahasa Inggris "Natural Science". Natural artinya ilmiah dan berhubungan dengan alam. Science artinya Ilmu Pengetahuan (Dewi, 2014). IPA adalah pengetahuan yang rasional dan objektif tentang alam semesta dengan segala isinya (Samatowa, 2010:3).

Pembelajaran IPA sangat berperan penting dalam proses pendidikan dan juga perkembangan teknologi. Namun kenyataan di lapangan upaya peningkatan kualitas pendidikan khususnya di SD pada hasil belajar mata pelajaran IPA masih kurang memuaskan. Mata pelajaran IPA masih dianggap sebagai pelajaran yang sulit dipahami dan kurang diminati siswa sehingga masih banyak siswa yang mengalami kesulitan dalam pembelajaran IPA. Pada saat proses pembelajaran masih banyak ditemui pelaksanaan pembelajaran yang kurang inovatif dan proses pembelajaran memiliki kecenderungan diterapkannya pembelajaran konvensional. Siswa kurang aktif dalam proses pembelajaran dikarenakan pembelajaran masih terfokus pada guru sebagai sumber utama pengetahuan. Pembelajaran konvensional biasanya dilaksanakan dengan pendekatan pembelajaran yang berpusat pada guru, yang artinya guru cenderung lebih mendominasi atau lebih aktif saat proses pembelajaran sehingga siswa akan terkesan pasif.

Masalah tersebut ditemukan di SD Gugus III Kecamatan Sukawati. Berdasarkan data studi dokumentasi yang dilakukan pada tanggal 3 dan 4 Januari 2018 diperoleh hasil tes akhir semester I siswa kelas V SD di gugus III Kecamatan Sukawati tahun pelajaran 2017/2018, khususnya pada mata pelajaran IPA pada Tabel 1. 
Tabel 1. Nilai Rata-Rata UAS IPA Siswa Kelas V SD di Gugus III Kecamatan Sukawati Tahun Pelajaran $2017 / 2018$

\begin{tabular}{ccccccc}
\hline No & Nama Sekolah & \multirow{2}{*}{$\begin{array}{c}\text { Jumlah } \\
\text { Siswa }\end{array}$} & KKM & Tuntas & $\begin{array}{c}\text { Belum } \\
\text { Tuntas }\end{array}$ & \multirow{2}{*}{$\begin{array}{c}\text { Persentase } \\
\text { Ketuntasan }\end{array}$} \\
\hline 1. & SD N 1 Batuan Kaler & 38 & 70 & 8 & 30 & $21,05 \%$ \\
\hline 2. & SD N 2 Batuan Kaler & 28 & 70 & 9 & 19 & $32,14 \%$ \\
\hline 3. & SD N 1 Batuan & 29 & 72 & 6 & 23 & $20,69 \%$ \\
\hline 4. & SD N 2 Batuan & 29 & 72 & 6 & 23 & $20,69 \%$ \\
\hline 5. & SD N 4 Batuan & 26 & 70 & 9 & 17 & $31,03 \%$ \\
\hline & Jumlah & 150 & & 38 & 112 & $25,12 \%$ \\
\hline
\end{tabular}

Berdasarkan Tabel 1, dapat dilihat bahwa dari 150 siswa kelas V di Gugus III Kecamatan Sukawati terdapat 112 siswa yang belum tuntas pada mata pelajaran IPA dan masih di bawah KKM. Sedangkan, hanya 38 siswa yang mampu mencapai KKM. Persentase keseluruhan siswa yang mencapai KKM hanya sebesar 25,12\%. Banyaknya siswa yang belum mampu mencapai KKM membuktikan bahwa hasil belajar siswa pada mata pelajaran IPA SD di Gugus III Kecamatan Sukawati masih rendah.

Permasalahan tentang kurang optimalnya proses pembelajaran IPA serta rendahnya hasil belajar IPA yang ditunjukkan dari hasil observasi, wawancara dan studi dokumentasi hasil tes akhir semester I siswa kelas V SD di gugus III Kecamatan Sukawati tahun pelajaran 2017/2018 disebabkan oleh beberapa faktor yaitu, (1) rendahnya hasil belajar IPA siswa, dikarenakan guru belum sepenuhnya menerapkan model pembelajaran yang inovatif, (2) pada penyajian materi IPA, guru kurang menggunakan media pembelajaran, (3) proses pembelajaran IPA cenderung dilaksanakan secara konvensional, (4) rendahnya keinginan siswa saat proses pembelajaran, (5) proses pembelajaran yang dilaksanakan kurang menyenangkan.

Berdasarkan uraian masalah tersebut, maka diperlukan suatu solusi untuk memecahkan masalah yang dihadapi khususnya pada masalah pembelajaran IPA. Salah satu solusinya adalah dengan merancang model pembelajaran kooperatif tipe Course Review Horay (CRH) bermediakan audio visual yang diharapkan tepat dalam melaksanakan proses pembelajaran siswa agar hasil belajar siswa pada mata pelajaran IPA dapat tercapai secara optimal.

Menurut Kurniasih \& Berlin (2016:80) menyatakan bahwa "Model Pembelajaran CRH merupakan modell pembelajaran yang dapat menciptakan suasana kelas menjadi meriah dan menyenangkan karena setiap siswa yang menjawab benar maka siswa tersebut diwajibkan berteriak 'Horay' atau yel-yel lainnya yang disukai". Model pembelajaran kooperatif tipe CRH dapat memacu siswa untuk saling berkompetisi serta melatih kerjasama antar siswa dalam kelompok dengan saling berdiskusi untuk menjawab pertanyaan-pertanyaan yang diberikan.

Kegiatan merancang proses pembelajaran yang inovatif dapat juga diintegrasikan dengan menggunakan media pembelajaran "Media pembelajaran dalam proses pembelajaran dapat membangkitkan keinginan, minat, motivasi dan rangsangan belajar" (Sugiantari, 2014). Penggunaan media pembelajaran pada saat proses pembelajaran sangat membantu keefektifan kegiatan pembelajaran dalam penyampaian pesan dan materi pelajaran. Melalui media pembelajaran proses pembelajaran lebih menarik dan tentunya menyenangkan, salah satu media yang dapat digunakan yaitu media audio visual. "Media audio visual adalah media yang mempunyai unsur suara dan unsur gambar, sehingga untuk menikmatinya diperlukan indera pendengaran dan penglihatan" (Tegeh, 2010:94). Dengan menggunakan media audio visual, penyampaian bahan ajar kepada peserta didik akan semakin lengkap dan optimal.

Hasil belajar merupakan sesuatu yang diperoleh siswa setelah mengikuti proses pembelajaran. Menurut Kunandar (2007) "hasil belajar adalah kemampuan siswa dalam memenuhi suatu tahapan pencapaian pengalaman belajar dalam satu kompetensi dasar". Menurut Abdurrahman (2003), "hasil belajar adalah kemampuan yang diperoleh anak setelah melalui kegiatan belajar (Ayuwanti ,2016).

Berdasarkan pemaparan di atas, maka tujuan dari penelitian ini adalah untuk mengetahui perbedaan yang signifikan hasil belajar IPA antara kelompok siswa yang mengikuti model pembelajaran kooperatif tipe Course Review Horay bermediakan audio visual dan kelompok siswa yang mengikuti pembelajaran konvensional pada siswa kelas V SD di Gugus III Kecamatan Sukawati Tahun Pelajaran $2017 / 2018$ 


\section{Metode}

Penelitian ini dilaksanakan di SD Gugus III Kecamatan Sukawati Tahun Pelajaran 2017/2018 pada siswa kelas V SD semester II dari tanggal 28 Maret sampai dengan 27 April 2018. Jenis penelitian yang dilakukan termasuk pada penelitian jenis Quasi Eksperimen (eksperimen semu). Populasi dalam penelitian ini adalah seluruh siswa kelas V di SD Gugus III Kecamatan Sukawati yang masih menerapkan KTSP. Banyaknya seluruh siswa adalah 150. Untuk mengetahui kemampuan seluruh siswa kelas V SD di Gugus III Kecamatan Sukawati tahun pelajaran 2017/2018 setara atau belum, maka terlebih dahulu dilakukan uji kesetaraan dengan menggunakan analisis varians satu jalur (ANAVA A).

Berdasarkan analisis ANAVA A pada taraf signifikansi 5\%, diperoleh nilai Fhitung=0,63. Nilai Ftabel pada dbantar $=4$ dan dbdalam $=145$ yaitu diperoleh Ftabel sebesar 2,43. Ini berarti bahwa harga Fhitung lebih kecil dari Ftabel yang berarti bahwa HO diterima. Jadi, tidak terdapat perbedaan hasil belajar IPA siswa kelas V SD di Gugus III Kecamatan Sukawati Tahun Pelajaran 2017/2018. Dengan demikian, populasi penelitian dinyatakan memiliki kesetaraan.

Selanjutnya dilakukan pengambilan sampel, untuk menentukan sampel yang digunakan dalam penelitian ini dilakukan melalui teknik random sampling. Pengundian tahap pertama diperoleh 2 sekolah yaitu SD Negeri 4 Batuan dan SD Negeri 2 Batuan Kaler. Selanjutnya, untuk menentukan kelompok kontrol dan kelompok eksperimen dilakukan undian tahap kedua diperoleh SD Negeri 4 Batuan sebagai kelompok kontrol yang mengikuti pembelajaran konvensional dan SD Negeri 2 Batuan Kaler sebagai kelompok eksperimen yang mengikuti model pembelajaran kooperatif tipe CRH bermediakan audio visual. Metode pengumpulan data yang digunakan adalah metode tes.

Penelitian ini menggunakan rancangan non-equivalen post-test only control group design, yang secara prosedural mengikuti pola seperti yang ditunjukkan pada Tabel 2.

Tabel 2. Non-Equivalen Post-test Only Control Group Design

\begin{tabular}{cccc}
\hline Kelompok & Perlakuan & \multicolumn{2}{c}{ Tes Akhir (Posttest) } \\
\hline $\mathrm{E}$ & $\mathrm{X}$ & $\mathrm{O}_{1}$ \\
\hline $\mathrm{K}$ & - & $\mathrm{O}_{2}$ \\
\hline
\end{tabular}

Berdasarkan desain di atas, dapat diterangkan sebagai berikut.

(dimodifikasi dari Dantes, 2017:17)

E : Kelompok eksperimen

K : Kelompok kontrol

$\mathrm{X} \quad$ : Diberikan perlakuan/treatment menggunakan model pembelajaran $C R H$ bermediakan audio visual

- $\quad$ : Pembelajaran Konvensional

$01 \quad$ : Post-test pada kelompok eksperimen

02 : Post-test pada kelompok kontrol

Untuk mengumpulkan data hasil belajar IPA, maka dalam penelitian ini menggunakan metode tes. Metode tes adalah "cara memperoleh data yang berbentuk suatu tugas yang harus dikerjakan oleh seorang atau sekelompok orang yang di tes dan dari tes dapat menghasilkan suatu skor" (Agung, 2014:92). Data hasil belajar IPA dalam penelitian ini berupa tes pilihan ganda (objektif). Data yang akan dikumpulkan diperoleh dari hasil post-test siswa kelompok eksperimen dan kontrol sesudah menerapkan model pembelajaran kooperatif tipe $C R H$ bermediakan audio visual serta pembelajaran konvensional pada siswa kelas V SD di gugus III Kecamatan Sukawati.

Instrumen disebut valid apabila benar-benar mampu mengukur apa yang semestinya diukur dengan instrumen tersebut. Sehingga, dengan kata lain instrumen yang digunakan untuk mengumpulkan data harus menjamin kebenaran data (Candiasa, 2010:21). Agar instrumen memenuhi syarat instrumen yang baik, maka dilakukan uji validitas isi, uji validitas butir, uji reliabilitas, uji tingkat kesukaran tes objektif, dan uji daya beda tes objektif.

Data hasil penelitian yang sudah dikumpulkan akan dianalisis secara bertahap yaitu dengan analisis statistik deskriptif, uji prasyarat, dan uji hipotesis.

Analisis statistik deskriptif meliputi menghitung mean, median, modus, standar deviasi dan varians. Sedangkan

uji prasyarat yang dilakukan adalah uji normalitas sebaran data dan uji homogenitas. Metode analisis data yang digunakan untuk menguji hipotesis menggunakan uji-t dengan rumus polled varians sebagai berikut. 


$$
t=\frac{\overline{X_{1}}-\overline{X_{2}}}{\sqrt{\frac{\left(n_{1}-1\right) s_{1}^{2}+\left(n_{2}-1\right) s_{2}^{2}}{n_{1}+n_{2}-2}\left(\frac{1}{n_{1}}+\frac{1}{n_{2}}\right)}}
$$

Keterangan :

$$
\begin{array}{ll}
\overline{X_{1}} & \text { : rata - rata skor dari kelompok eksperimen } \\
\overline{X_{2}} & \text { : rata - rata skor dari kelompok kontrol } \\
n_{1} & \text { : banyak siswa kelompok eksperimen } \\
n_{2} & \text { : banyak siswa kelompok kontrol } \\
s_{1}^{2} & \text { : varian kelompok eksperimen } \\
s_{2}^{2} & \text { : varian kelompok kontrol }
\end{array}
$$

Dengan kriteria jika harga $t_{\text {hitung }}<t_{\text {tabel, }}$, maka $\mathrm{H}_{0}$ diterima dan $\mathrm{H}_{1}$ ditolak, dan jika $t_{\text {hitung }} \geq t_{\text {tabel, }}$, maka $\mathrm{H}_{0}$ ditolak dan $\mathrm{H}_{1}$ diterima. Pengujian dilakukan pada taraf signifikansi $5 \%$ dengan derajat kebebasan $\mathrm{dk}=$ $\mathrm{n}_{1}+\mathrm{n}_{2}-2$.

\section{Hasil dan Pembahasan}

Data yang terkumpul dalam penelitian ini disusun sesuai dengan keperluan analisis. Data diperoleh dari 54 orang siswa, terdiri dari 28 orang siswa kelas V SD N 2 Batauan Kaler sebagai kelompok eksperimen dan 26 orang siswa kelas V SD N 4 Batuan sebagai kelompok kontrol.

Data hasil belajar IPA kelompok siswa yang mengikuti model pembelajaran kooperatif tipe CRH bermediakan audio visual dan kelompok siswa yang mengikuti pembelajaran konvensional diperoleh dari post-test yang berjumlah 30 soal yang telah divalidasi.

Hasil penelitian ini disajikan dalam bentuk deskripsi data hasil penelitian post-test pada kelompok eksperimen dan kontrol. Adapun deskripsi pada kedua kelompok disajikan pada Tabel 3.

Tabel 3. Deskripsi Data Hasil Belajar IPA

\begin{tabular}{ccc}
\hline \multirow{2}{*}{ Statistik } & \multicolumn{2}{c}{ Hasil Belajar IPA } \\
\cline { 2 - 3 } & Kelompok Eksperimen & Kelompok Kontrol \\
\hline Jumlah Responden & 28 & 26 \\
\hline Mean & 23,58 & 15,23 \\
\hline Median & 24 & 15,17 \\
\hline Modus & 24,3 & 15,5 \\
\hline Standar Deviasi & 3,81 & 3,80 \\
\hline Varians & 14,53 & 14,48 \\
\hline Skor Maksimum & 29 & 24 \\
\hline Skor Minimum & 14 & 9 \\
\hline Konversi Rata-rata Skala Penilaian & Kategori Sangat Tinggi & Kategori Sedang
\end{tabular}

Berdasarkan Tabel 3, diketahui bahwa rata-rata hasil belajar IPA kelompok siswa yang mengikuti model pembelajaran kooperatif tipe $C R H$ berbantuan media audio visual sebesar 23,58 sedangkan ratarata hasil belajar IPA kelompok siswa yang mengikuti pembelajaran konvensional sebesar 15,23. Hal ini menunjukkan bahwa, rata-rata hasil belajar IPA kelompok siswa yang mengikuti model pembelajaran kooperatif tipe $C R H$ bermediakan audio visual lebih tinggi dibandingkan dengan kelompok siswa yang mengikuti pembelajaran konvensional. Data hasil belajar IPA kelompok eksperimen dapat disajikan ke dalam bentuk poligon, seperti pada Gambar 1 . 


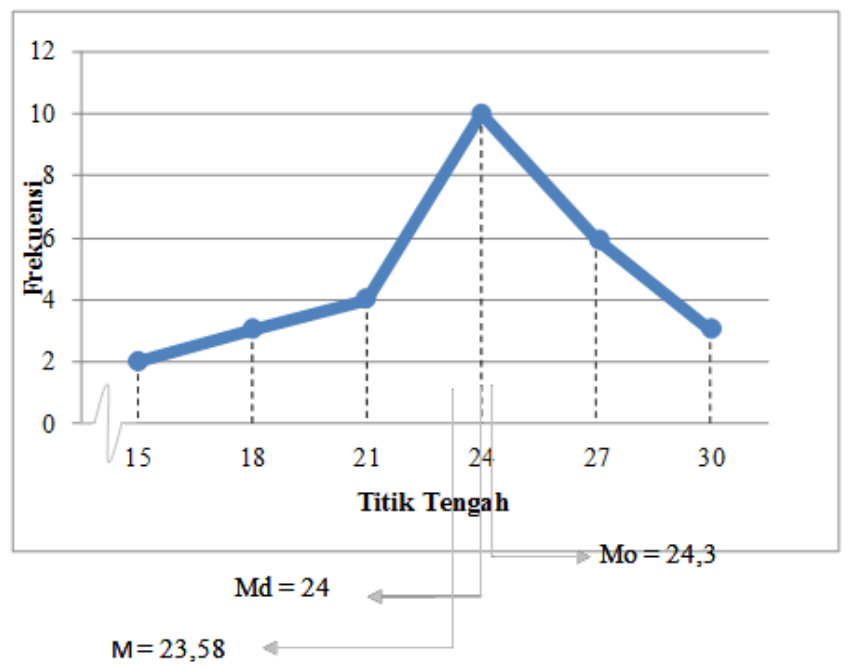

Gambar 1. Kurva Poligon Hasil Belajar IPA Kelompok Eksperimen

Berdasarkan kurva poligon data hasil belajar IPA kelompok siswa yang mengikuti model pembelajaran kooperatif tipe $C R H$ bermediakan audio visual menunjukkan Mo > Md > M $(24,3>24>$ 23,58). Hal ini berarti, sebagain besar skor kelompok siswa yang mengikuti model pembelajaran kooperatif tipe $C R H$ bermediakan audio visual cenderung tinggi.

Data hasil belajar IPA kelompok kontrol dapat disajikan ke dalam bentuk poligon, seperti pada Gambar 2.

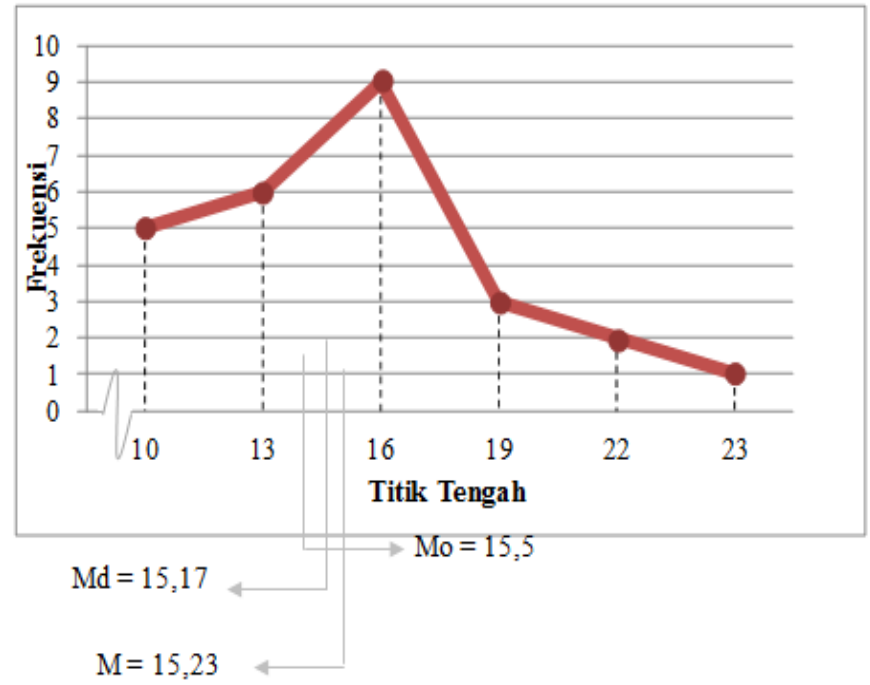

Gambar 2. Kurva Poligon Hasil Belajar IPA Kelompok Kontrol

Berdasarkan kurva poligon data hasil belajar IPA kelompok siswa yang mengikuti pembelajaran konvensional menunjukkan Mo $<\mathrm{Md}<\mathrm{M}(15,5<15,17<15,23)$. Hal ini berarti sebagian besar skor kelompok siswa yang mengikuti pembelajaran konvensional cenderung rendah.

Pengujian prasyarat analisis dilakukan untuk mengetahui hasil post-test berdistribusi normal dan varians antar kelompok homogen.

Berdasarkan hasil perhitungan uji normalitas post-test kelompok eksperimen $\chi^{2}$ selanjutnya di konsultasikan ke tabel chi-kuadrat pada taraf signifikansi 5\%. Berdasarkan tabel chi-kuadrat pada taraf signifikansi 5\% dengan $\mathrm{dk}=6-2-1=3$, di dapat harga chi-kuadrat sebesar 7,815 dan chi kuadrat hitung sebesar 3,655 sehingga dapat diketahui bahwa $\chi^{2}$ hitung $(3,655)<\chi^{2}$ tabel $(7,815)$ maka dapat disimpulkan bahwa data hasil belajar IPA kelompok eksperimen berdistribusi normal. Sedangkan hasil 
perhitungan uji normalitas kelompok kontrol yaitu $\chi^{2}$ hitung $(3,283)<\chi^{2}$ tabel $(7,815)$ maka dapat disimpulkan bahwa data hasil belajar IPA kelompok kontrol berdistribusi normal.

Uji homogenitas sangat diperlukan sebelum membandingkan dua kelompok atau lebih agar perbedaan yang ada bukan disebabkan oleh adanya perbedaan data dasar (ketidakhomogenan kelompok yang dibandingkan). Untuk itu dilakukan uji Fisher (F). Berdasarkan hasil perhitungan uji homogenitas kelompok eksperimen dan kelompok kontrol diperoleh $\mathrm{F}_{\text {hitung }}=1,00$ dan $\mathrm{F}_{\text {tabel }}=2,25$ pada taraf signifikansi 5\% dan derajat kebebasan (dk) untuk pembilang $28-1=27$ dan derajat kebebasan $(\mathrm{dk})$ untuk penyebut 26-1 $=25$. Dengan demikian, $F_{\text {hitung }}<\mathrm{F}_{\text {tabel }}$, sehingga data hasil belajar IPA kelompok eksperimen dan kelompok kontrol adalah homogen.

Berdasarkan uji prasyarat analisis data, yaitu uji normalitas dan homogenitas diperoleh bahwa sebaran data hasil belajar IPA kelompok eksperimen dan kelompok kontrol berdistribusi normal dan memiliki varians homogen. Untuk mengetahui pengaruh model pembelajaran koopertaif tipe $C R H$ bermediakan audio visual terhadap hasil belajar IPA siswa, dilakukan pengujian terhadap hipotesis nol $\left(\mathrm{H}_{0}\right)$. Oleh sebab itu, dilanjutkan pada pengujian hipotesis dengan polled varians.

Hasil analisis uji-t dapat dilihat pada Tabel 4

Tabel 4. Hasil Uji Hipotesis

\begin{tabular}{|c|c|c|c|c|c|c|c|}
\hline No & $\begin{array}{c}\text { Kelompok Data Hasil } \\
\text { Belajar }\end{array}$ & Varians & $\mathrm{N}$ & $\mathrm{Db}$ & $\mathrm{t}_{\text {hitung }}$ & $t_{\text {tabel }}$ & Kesimpulan \\
\hline 1 & $\begin{array}{lr}\text { Kelompok siswa yang } \\
\text { mengikuti } & \text { model } \\
\text { pembelajaran kooperatif } \\
\text { tipe } C R H \text { bermediakan } \\
\text { audio visual }\end{array}$ & 14,53 & 28 & 52 & 8,35 & 2,021 & $\begin{array}{c}\mathrm{t}_{\text {hitung }}>\mathrm{t}_{\text {tabel }} \\
\mathrm{H}_{0} \text { ditolak }\end{array}$ \\
\hline 2 & $\begin{array}{l}\text { Kelompok siswa yang } \\
\text { mengikuti pembelajaran } \\
\text { konvensional }\end{array}$ & 14,48 & 26 & & & & \\
\hline
\end{tabular}

Berdasarkan hasil perhitungan uji-t Tabel 4, diperoleh thitung adalah 8,35. Sedangkan ttabel pada taraf signifikansi $5 \%$ dan $d b=(28+26-2)=52$ adalah 2,021 . Hal ini berarti thitung $(8,35)$ lebih besar dari ttabel $(2,021)$ (thitung $>$ ttabel), sehingga H0 ditolak dan H1 diterima. Jadi, terdapat perbedaan yang signifikan hasil belajar IPA antara kelompok siswa yang mengikuti model pembelajaran kooperatif tipe Course Review Horay bermediakan audio visual dan kelompok siswa yang mengikuti pembelajaran konvensional pada siswa kelas V SD di Gugus III Kecamatan Sukawati tahun pelajaran 2017/2018.

Perbedaan hasil belajar antara kelompok siswa yang mengikuti model pembelajaran kooperatif tipe Course Review Horay bermediakan audio visual dan kelompok siswa yang mengikuti pembelajaran konvensional disebabkan oleh beberapa hal terkait dengan pelaksanaan pembelajaran. Pertama, model pembelajaran kooperatif tipe CRH memberikan kesempatan kepada siswa untuk membentuk kelompok dan berdiskusi. Hal tersebut menyebabkan siswa terlatih untuk menyampaikan pendapatnya dan berpartisipasi aktif dalam kelompok tersebut. Temuan ini didukung oleh pendapat dari Shoimin (2014) yang menyatakan bahwa kegiatan pembelajaran dengan menggunakan model pembelajaran CRH dapat melatih kerjasama siswa dalam kelompok.

Kedua, ketika guru mengajukan beberapa pertanyaan untuk apersepsi yang terkait dengan materi siswa sangat antusias dalam menjawab peratanyaan dari guru dan dapat menjawab pertanyaan tersebut dengan tepat, berarti siswa telah mampu mengkonstruksi pengetahuannya sendiri. Temuan ini di dukung oleh pendapat dari Ahmad Susanto (2013:16) yang menyatakan bahwa kemauan belajar yang tinggi disertai dengan rasa tanggung jawab yang besar tentunya berpengaruh positif terhadap hasil belajar yang diraihnya.

Kemudian siswa juga tampak penasaran dengan media yang disediakan oleh guru. Guru menggunakan media audio visual dalam penyampaian materi berupa video pembelajaran maupun film yang terkait dengan materi yang akan disampaikan. Tentunya dengan menggunakan media audio visual penyampaian materi akan menarik, dan menyenangkan sehingga siswa merasa adanya hiburan dalam proses pembelajaran. Seluruh siswa menyimak dengan baik media audio visual yang ditayangkan oleh guru. Miarso (dalam Tegeh, 2010: 6) mengungkapkan media pembelajaran adalah segala sesuatu yang dapat digunakan untuk merangsang pikiran, perasaan, perhatian dan kemauan siswa sehingga dapat mendorong terjadinya proses belajar pada diri siswa. Salah satu media pembelajaran yang ada adalah media audio visual. Menurut Tegeh (2010:94) media audio visual adalah "media yang mempunyai unsur suara dan unsur gambar, sehingga untuk menikmatinya diperlukan indera pendengaran dan penglihatan". 
Ketiga, dalam kegiatan menjawab soal yang diberikan oleh guru setiap kelompok memiliki strategi tersendiri untuk bisa menjawab pertanyaan guru dengan benar dan dapat membentuk jawaban secara vertikal, horizontal, maupun diagonal. Selain itu juga siswa diberikan kesempatan untuk berteriak horay maupun menyanyikan yel-yel yang telah disepakati bersama kelompok hal ini dapat menciptakan suasana kelas yang berkompetisi, meriah dan menyenangkan. Siswa dapat sekaligus dapat aktif dan meningkatkan kreatifitas yang dimiliki selama proses pembelajaran. Temuan ini didukung oleh pendapat Kurniasih dan Berlin (2016) yang menyatakan bahwa model pembelajaran kooperatif tipe CRH merupakan model pembelajaran yang menarik dan mendorong siswa untuk dapat terjun dalam kegiatan pembelajaran, pembelajarannya tidak monoton karena diselingi sedikit hiburan untuk siswa sehingga suasana tidak menegangkan, dan siswa lebih semangat belajar karena suasana pembelajaran berlangsung menyenangkan.

Keempat, kegiatan bermain akan memberikan kesan yang menarik dan menyenangkan kepada siswa, karena kegiatan bermain sesuai dengan salah satu karakteristik siswa SD. Dengan kegiatan bermain, siswa dapat meningkatkan kreativitas yang dimiliki, menikmati proses pembelajaran yang menyenangkan, serta memperoleh pengetahuan melalui pengalaman bermain yang dilakukan oleh siswa SD. Hal ini tentunya berpengaruh baik terhadap hasil belajar yang akan diperoleh oleh siswa. Temuan ini dipertegas oleh pendapat Soefandi dan Ahmad (2009), yang menyatakan bahwa bermain memberikan kesempatan kepada anak untuk meningkatkan kreativitasnya, dapat merangsang anak untuk aktif dalam proses pembelajaran, sehingga akan berpengaruh terhadap hasil belajar siswa.

Kelima, pemberian reward dan reinforcement kepada siswa berupa tanda benar (?) dan langsung berteriak horay atau yel lainnya yang dapat memberikan suasana yang menyenangkan. Dalam kegiatan pembelajaran tentunya ada kelompok yang mendapatkan "horay" terbanyak, kelompok tersebutlah yang menang dan mendapatkan reward dari guru. dengan adanya pemberian reward atau pengharagaan akan membuat siswa lebih aktif dan lebih termotivasi dalam mengikuti kegiatan pembelajaran. Dengan demikian, hasil belajar siswa pun akan meningkat. Temuan ini dipertegas oleh pendapat Bamawi dan Arifin (2012) yang menyatakan bahwa penguatan dalam bentuk symbol, dapat berupa tanda centang (?), pada hasil pekerjaan siswa dapat meningkatkan aktivitas siswa sehingga dapat menghasilkan hasil belajar yang maksimal.

Perbedaan cara pembelajaran antara pembelajaran dengan menggunakan model pembelajaran kooperatif tipe CRH bermediakan audio visual dan pembelajaran konvensional tentunya akan memberikan dampak yang berbeda pula terhadap hasil belajar siswa. Dalam kegiatan pembelajaran konvensional, guru bertindak selaku pelaksana kegiatan pembelajaran. Umumnya yang dilakukan guru yaitu ceramah, mendemonstrasikan sesuatu, memberikan tugas dan mendiskusikan apa yang telah dilihat atau didengar, sehingga guru lebih aktif daripada siswa karena aktivitas siswa hanya duduk, mendengarkan, mencatat, dan menghafal. Hal ini menyebabkan aktivas siswa selama kegiatan pembelajaran cenderung kurang memperhatikan penjelasan guru.

Hasil dan temuan mengenai model pembelajaran CRH bermediakan audio visual sejalan dengan penelitian sebelumnya yang dilakukan oleh Widya (2014), berdasarkan penelitian tersebut didapatkan hasil bahwa rata-rata hasil belajar IPA kelas eksperimen lebih tinggi daripada rata-rata hasil belajar kelas kontrol.

Berdasarkan pemaparan di atas, dapat diinterpretasikan bahwa pembelajaran menggunakan model pembelajaran kooperatif tipe CRH bermediakan audio visual berpengaruh terhadap hasil belajar IPA pada siswa kelas V SD di Gugus III Kecamatan Sukawati Tahun Pelajaran 2017/2018

\section{Simpulan dan Saran}

Berdasarkan hasil pengujian hipotesis dan pembahasan, maka simpulan dari penelitian ini yaitu terdapat perbedaan yang signifikan hasil belajar IPA antara kelompok siswa yang mengikuti model pembelajaran kooperatif tipe Course Review Horay bermediakan audio visual dan kelompok siswa yang mengikuti pembelajaran konvensional pada siswa kelas V SD di Gugus III Kecamatan Sukawati Tahun Pelajaran 2017/2018. Sehingga model pembelajaran kooperatif tipe CRH bermediakan audio visual memiliki pengaruh yang signifikan terhadap hasil belajar IPA siswa kelas V SD di Gugus III Kecamatan Sukawati tahun pelajaran 2017/2018.

Saran

Saran-saran yang dapat disampaikan berdasarkan penelitian yang telah dilakukaan adalah sebagai berikut, 1) kepada siswa di sekolah dasar, diharapkan dapat mengikuti proses pembelajaran dengan model pembelajaran kooperatif tipe CRH bermediakan audio visual dengan baik dan aktif, sehingga dapat mencapai hasil belajar IPA yang optimal, 2) kepada guru, diharapkan agar lebih berinovasi dalam pembelajaran dengan menerapkan berbagai model pembelajaran inovatif, salah satunya model 
pembelajaran kooperatif tipe $\mathrm{CRH}$ bermediakan audio visual yang dapat menunjang kegiatan belajar mengajar serta untuk meningkatkan hasil belajar siswa, 3) kepada Kepala Sekolah, diharapkan dapat memberikan kontribusi bagi sekolah dalam pengembangan pendidikan karena bertambahnya raga $m$ atau variasi model pembelajaran serta dapat menggunakan hasil penelitian ini sebagai bahan acuan pedoman untuk mengadakan pelatihan bagi guru-guru dalam melaksanakan pembelajaran dengan menggunakan model pembelajaran CRH bermediakan audio visual untuk meningkatkan hasil belajar siswa, 4) kepada peneliti lain, penelitian ini terbatas pada hasil belajar IPA dan standar kompetensi yang digunakan adalah memahami perubahan yang terjadi di alam dan hubungannya dengan penggunaan sumber daya alam pada kelas V. Untuk peneliti lain yang ingin meneliti hasil belajar IPA dengan menggunakan model pembelajaran kooperatif tipe $\mathrm{CRH}$ bermediakan audio visual dapat mengambil standar kompetensi maupun materi pelajaran yang lain guna memberikan hasil yang beragam dan lebih baik.

\section{Daftar Rujukan}

Agung, A. A .G. 2014. Metodologi Penelitian Pendidikan. Malang: Aditya Media Publishing.

Ayuwanti, Irma. 2016 . Meningkatkan Aktivitas Dan Hasil Belajar Matematika Menggunakan Model Pembelajaran Kooperatif Tipe Group Investigation Di Smk Tuma'ninah Yasin Metro . Jurnal SAP Vol. 1 No. 2 Desember 2016 ISSN: 2527-967X

Bamawi dan Mohammad A, 2012. Etika dan Profesi Kependidikan. Ar-Ruzz Media, Jakarta.

Candiasa, I. M. 2010. Pengujian Instrumen Penelitian Disertai Aplikasi ITEMAN dan BIGSTEPS. Singaraja: Undiksha Press.

Dantes, N. 2017. Desain Eksperimen dan Analisis Data. Depok: Rajawali Pers

Depdiknas. 2003. Peraturan Pemerintah Nomor 20 Tahun 2003 tentang Sistem Pendidikan Nasional. Jakarta: BNSP.

Dewi, N. M. M. 2014. "Pengaruh Model Pembelajaran Kooperatif Tipe Course Review Horay (CRH) Terhadap Hasil Belajar IPA Pada Siswa Kelas V SD Tahun Pelajaran 2013/2014 di Gugus IV Kecamatan Buleleng". Jurnal Mimbar PGSD Universitas Pendidikan Ganesha. Vol 2 No: 1 Tahun 2014. (Diakses tanggal 24 Desember 2017)

Koyan, W. 2012. Statistik Pendidikan: Teknik Analisis Data Kuantitatif. Singaraja: Universitas Pendidikan Ganesha Press.

Kurniasih, I dan Berlin S. 2016. Ragam Pengembangan Model Pembelajaran Untuk Peningkatan Profesionalisme Guru. Jakarta: Kata Pena.

Munirah. 2015. Sistem Pendidikan Di Indonesia: Antara Keinginan Dan Realita . AULADUNA, VOL. 2 NO. 2 DESEMBER 2015: 233-245 . Auladuna, Vol. 2 No. 2 Desember 2015: 233-245

Nurkholis. 2013 . Pendidikan Dalam Upaya Memajukan Teknologi . Jurnal Kependidikan, Vol. 1 No. 1 Nopember 2013.

Samatowa, U. 2011. Pembelajaran IPA di Sekolah Dasar. Jakarta: PT Indeks

Shoimin, A. 2014. 68 Model Pembelajaran Inovatif dalam Kurikulum 2013. Yogyakarta: Ar-Ruzz Media.

Sugiantari, N. P. E. 2014. "Pengaruh Model Pembelajaran Generatif Berbantuan Media Audio Visual Terhadap Hasil Belajar IPA Siswa Kelas V SD Gugus V Mengwi”. Jurnal Mimbar PGSD Universitas Pendidikan Ganesha. Vol 2 No:1 Tahun 2014. (Diakses tanggal 24 Desember 2017

Soefandi dan Ahmad. 2009. Strategi Mengembangkan Kecerdasan Anak. Jakarta: Bee Media Indonesia. 
Susanto, A. 2014. Teori Belajar \& Pembelajaran di Sekolah Dasar. Jakarta: Kencana Prenadamedia Group.

Tegeh, M. 2010. Media Pembelajaran. Singaraja: Universitas Pendidikan Ganesha.

Trianto. 2009. Model Pembelajaran Terpadu: Konsep, Strategi, dan Implementasinya dalam Kurikulum Tingkat Satuan Pendidikan (KTSP). Jakarta: Bumi Aksara.

Widya, N. M. 2014. "Pengaruh Model Pembelajaran Kooperatif Tipe Course Review Horay Berbantuan Media Audio Visual Terhadap Hasil Belajar IPA Pada Siswa Kelas V SD Saraswati 2 Denpasar".Jurnal Mimbar PGSD Universitas Pendidikan Ganesha. Vol 2 No:1 Tahun 2014. (Diakses tanggal 24 Desember 2017). 